\title{
The Correlation of Metacognitive and Learning Motivation in Medical Students Academic Integrity in a Medical School
}

\author{
Destiana Putri Nurfauziah ${ }^{1 *}$, Agneta Irmarahayu ${ }^{2}$, Hikmah Muktamiroh $^{2 *}$ \\ ${ }^{1}$ Fakultas Kedokteran Universitas Pembangunan Nasional Veteran Jakarta \\ ${ }^{2}$ Departemen Pendidikan Kedokteran Fakultas Kedokteran Universitas Pembangunan Nasional Veteran Jakarta \\ "Corresponding author.Email: hikmahmuktamiroh@upnvj.ac.id; destianaputrin@upnvj.ac.id
}

\begin{abstract}
Background: The Academic integrity is a major part of academic culture in the sense of being obedient to basic principles, including academic honesty, mutual trust, mutual openness, mutual respect, and a sense of responsibility. However, there are few data on understanding of academic integrity among medical students. It is expected that the performance of student academic integrity can further improve the behaviour of student academic integrity. Student performance can be improved through metacognitive and learning motivation.

Aims: To determine the correlation between metacognitive and learning motivation with the academic integrity among pre-clinical medical students

Methods: This study used proportional stratified sampling, sample size were 156 medical students of batch 2 nd, 3 th, 4th, data were collected from adaptation of metacognitive activities inventory, academic motivation scale, and academic integrity. The research design used was the cross sectional method. Data analysis in this study used the Chi-square test. Result: The results of the statistical test, there was no correlation between metacognitive and academic integrity $(\mathrm{p}=0.365)$ and learning motivation with integrity $(\mathrm{p}=0.077)$

Conclusion and Recommendation: There was no correlation between metacognitive and learning motivation with academic integrity of preclinical medical students. External factor are further can improve the academic integrity of the student.
\end{abstract}

Keywords: Metacognitive, Motivation, Integrity

\section{INTRODUCTION}

Medical and health professionals have agreed on professionalism. However, according to Cruess [1], the majority of components of professionalism are implicit understanding. For instance, professionalism is a competency mapped into doctor competency standard [2]. However, Purnamasari et al suggested that only some institutions integrate professionalism in their curriculum. Implementation and assessment of professionalism in medical education is yet very basic. This is proven in previous research that found only some institutions integrated professionalism in their curriculum [3].

Professionalism in medicine is formed from several components of behavior, including altruism, competence, honesty and integrity, performance, management, and respect for others and humanism [3]. One of the components of professional behavior is academic integrity of students since college [4]. Academic integrity is a major part of academic culture in the sense of being obedient to basic principles, including academic honesty, mutual trust, mutual openness, mutual respect, and a sense of responsibility [5]. Professionalism cannot be separated from integrity issue because professionalism requires unwavering high integrity [6]. Despite the many developments in publication on professionalism, there are few data on the understanding of academic integrity among medical students [7]. This is proven in Herqutanto that there are nearly 40 similar writings in learning module of Faculty of Medicine - University of Indonesia [8]. In addition, the result of research conducted by Maharani with students at Faculty of Medicine - UPN Veteran Jakarta as the sample revealed that the majority of students had moderate academic integrity behavior [9]. Violation of basic principles that must be met is a crucial problem because medical students in the future are 
expected to be doctors who are required to be professional [10].

Development of academic integrity education is expected to improve students' academic integrity performance which is further expected to improve their academic integrity behavior [10]. In this condition, students can use metacognitive awareness which allows them to plan, monitor, and prioritize learning strategies that can improve their performance [11] . If students have metacognitive ability, they tend to be able to apply their learning strategies when studying, therefore they will be better prepared to take part in studying [12].

There are other aspects that can influence student performance, one of which is motivation [13] Motivation is basically divided into two, namely intrinsic motivation and extrinsic motivation. Intrinsic motivation is a motivation that comes from an internal urge to act, that causes a person to feel happy and satisfied after completing certain activities, while extrinsic motivation is the urge to do something to get a reward or other positive external consequences [14] Another factor that can influence academic integrity is academic anxiety [15] Academic anxiety is resulted from fear of failure in learning [16] [17]. Students who tend to have extrinsic motivation usually have a higher risk of failure than those who have intrinsic motivation [18] The risk of failure in extrinsic motivation can ultimately result in a violation of academic integrity.

Based on the description above, researcher is interested to conduct a research titled "The Relationship between Metacognitive and Learning Motivation with Academic Integrity in Pre-clinical Students at The Faculty of Medicine - Universitas Pembangunan Nasional Veteran Jakarta in 2020".

\subsection{Aims}

To determine the relationship between metacognitive and learning motivation with academic integrity in pre-clinical students at the Faculty of Medicine - Universitas Pembangunan Nasional Veteran Jakarta in 2020.

\section{METHODS}

\subsection{Research Design}

The type of research used was analytical. The method used was a quantitative research method. The research design used was a cross-sectional approach in order to determine the relationship between metacognitive and learning motivation with academic integrity in students at the Faculty of Medicine Universitas Pembangunan Nasional Veteran Jakarta.

\subsection{Population and Sample}

Population in this research was 444 students at the Faculty of Medicine, comprised of pre-clinical students in the $2^{\text {nd }}, 3^{\text {rd }}$, and $4^{\text {th }}$ year. The number of sample used was 156 students comprised of pre-clinical students in the $2^{\text {nd }}, 3^{\text {rd }}$, and $4^{\text {th }}$ year who met the inclusion criteria.

\subsection{Sampling Technique}

This research used probability sampling, namely simple random sampling. The sampling technique used was proportional stratified random sampling technique. In order to represent the population, it is taken randomly from each sampling unit, in which the sample was based on students' educational level at the Faculty of Medicine, including the $2^{\text {nd }}, 3^{\text {rd }}$, and $4^{\text {th }}$ year.

\subsection{Data Collection}

This research was conducted online using questionnaires on Google Form on October 2020.

\subsection{Research Instrument}

The instruments used in this research were Metacognitive Awareness Inventory by Sperlik et al (2002) which had been translated by Abdullah and Soemantri [19], the short version by Natalya from Motivation Academic Inventory developed by Vallerand et al [19] , and Academic Integrity by Roff which had been used by Musharyanti and adapted by Maharani and that had been valid and reliable [9].

\subsection{Research Procedure}

This research has received ethical clearance from Research Ethics Committee of Universitas Pembangunan Nasional and was carried out after obtaining consent through informed consent prior to data collection.

The data obtained from the questionnaires on Google form was divided into 5 parts. The first part was the respondent's consent form, the second part was the respondent's identity, the third part was Metacognitive questionnaire, the fourth part was learning motivation questionnaire, and the last part was academic integrity questionnaire.

\subsection{Data Analysis}

The number of sample was determined using a formula for different proportions, therefore the number of sample needed in this research was 156 students.

Researcher used univariate and bivariate data analysis in this research. The type of test used was independent categorical comparative hypothesis test with ordinal scale, namely Chi-Square test. To do the ChiSquare test, it is necessary to meet the requirements first Namely the cells that have an expected count $<5$, or a maximum of $20 \%$ of the number of cells. In this research, the Chi Square test could not be met, therefore the alternative test used was cell merging. 


\section{RESULT}

\subsection{Metacognitive}

Table 1. Respondents' Metacognitive Ability

\begin{tabular}{lll} 
Metacognitive & Frequency & Percentage (\%) \\
Can Not Really & 1 & 0.6 \\
Development & 10 & 6.4 \\
Ok & 123 & 78.8 \\
Super & 22 & 14.1 \\
\hline Total & 156 & 100 \\
\hline
\end{tabular}

Source: Primary Data, 2020

Table 1 shows that the majority of respondents were students who had metacognitive ability in "good" category, totaling 123 students $(78.8 \%)$.

\subsection{Learning Motivation}

Table 2. Respondents' Learning Motivation

\begin{tabular}{lll}
$\begin{array}{l}\text { Learning } \\
\text { motivation }\end{array}$ & Frequency & Percentage (\%) \\
\hline Low & 23 & 14.7 \\
Moderate & 114 & 73.1 \\
High & 19 & 12.2 \\
\hline Total & 156 & 100 \\
\hline
\end{tabular}

Source: Primary Data, 2020

Table 2 shows that the majority of respondents were students who had moderate learning motivation, totaling 114 students $(73.1 \%)$. The moderate motivation might be due to the absence of special technique used by the Faculty of Medicine - UPN Veteran Jakarta to develop its curriculum. Therefore, the motivation that can enhance deep learning and improve one's performance, and the creativity that plays an important role in professional identity, have not been fully built [21].

\subsection{Academic Integrity Behaviour}

Table 3. Respondents' Academic Integrity Behavior

\begin{tabular}{lll}
$\begin{array}{l}\text { Academic } \\
\text { Integrity }\end{array}$ & Frequency & Percentage $(\%)$ \\
Low & 18 & 11.5 \\
Moderate & 118 & 75.6 \\
High & 20 & 12.8 \\
\hline Total & 156 & 100 \\
\hline
\end{tabular}

Source: Primary Data, 2020

Table 3 shows that the majority of respondents were students who had moderate academic integrity behavior, totaling 118 students $(75.6 \%)$. This is in line with a research in which medical students in Jakarta were the sample [10]. The research revealed that the majority of students had moderate academic integrity behavior. Another research from Maharani also found the majority of students had moderate academic integrity behavior at the Faculty of Medicine - UPN Veteran Jakarta [9].

\subsection{Correlation between Metacognitive and Academic Integrity}

Table 4. Correlation between metacognitive and Academic Integrity

\begin{tabular}{|c|c|c|c|c|c|c|c|}
\hline \multirow{3}{*}{ Metacognitive } & \multicolumn{4}{|c|}{ Academic Integrity } & \multirow{2}{*}{\multicolumn{2}{|c|}{ Total }} & \multirow{3}{*}{$\mathrm{P}$} \\
\hline & \multicolumn{2}{|c|}{ Low } & \multicolumn{2}{|c|}{ High } & & & \\
\hline & $\mathrm{n}$ & $\%$ & $\mathrm{n}$ & $\%$ & $\mathrm{n}$ & $\%$ & \\
\hline Development & 0 & 0 & 11 & 7.1 & 11 & 7.1 & \\
\hline $\mathrm{Ok}$ & 18 & 11.5 & 127 & 81.4 & 145 & 92.9 & 0.365 \\
\hline Total & 18 & 11.5 & 138 & 88.5 & 156 & 100 & \\
\hline
\end{tabular}

Source: Primary Data, 2020

Table 4 shows that each metacognitive ability of students at the Faculty of Medicine - UPN Veteran Jakarta had the highest percentage of academic integrity behavior in "high" category. In "good" metacognitive ability, ratio of the percentage level of academic integrity was $11.5 \%$ "low" and $81.4 \%$ "high". In "development" metacognitive ability, ratio of the percentage level of academic integrity was $0 \%$ "low" and 7.1\% "high".

The results of bivariate test using cell merging showed $p$-value of 0.365 ( $p>0.05)$ which indicates that there was no relationship between metacognitive and academic integrity. The absence of relationship between the two variables cannot be explained. However, it can be seen from the cognitive aspect in Andiwatir and Khakim which argues that only intervening in one's cognitive aspect is not adequate to reduce cheating behavior. The most important thing is the student factors, along with their environment, in which these two are external factors. This research suggests that there are other external components that can influence academic integrity behavior [22]. The opinion above is in line with the research of Jiang et al which shows that there are other factors that contribute in affecting the behavior of academic integrity, specifically time management, peer pressure and also academic ability in this condition, for example in achieving good grades or achievement problems can be a pressure on the academic ability of each student [23]. There are also other factors that have a stronger influence on the academic integrity of students. One of them is in the results of Maharani's research that there is a relationship between parenting styles and student academic integrity [9].

\subsection{Correlation Between Learning Motivation and Academic Integrity}

Table 5. Correlation between Learning Motivation and Academic Integrity

\begin{tabular}{cccccccc}
\hline \multirow{2}{*}{$\begin{array}{c}\text { Learning } \\
\text { Motivation }\end{array}$} & \multicolumn{4}{c}{ Academic Integrity } & \multicolumn{2}{c}{ Total } & \multirow{2}{*}{ P } \\
\cline { 2 - 6 } & \multicolumn{2}{c}{ Low } & \multicolumn{2}{c}{ High } & & \\
\cline { 2 - 6 } & $\mathrm{n}$ & $\%$ & $\mathrm{n}$ & $\%$ & $\mathrm{n}$ & $\%$ & \\
\hline Low & 0 & 0 & 23 & 14.7 & 23 & 14.7 & \\
High & 18 & 11.5 & 115 & 73.7 & 133 & 85.3 & 0.077 \\
\hline Total & 18 & 11.5 & 138 & 88.5 & 156 & 100 & \\
\hline
\end{tabular}

Source: Primary Data, 2020 
Table 5 shows that students at the Faculty of Medicine - UPN Veteran Jakarta had "moderate" learning motivation, totaling 114 respondents $(73.1 \%)$. Meanwhile, 23 respondents $(14.7 \%)$ had "low" learning motivation, and only 19 respondents $(12.2 \%)$ had "high" learning motivation.

Based on the results of bivariate test using cell merging, it shows that the $\mathrm{p}$-value was 0.077 ( $\mathrm{p}>0.05$ ). This indicates that there was no relationship between learning motivation and academic integrity. The absence of relationship between the two variables was because, according to Jordan, motivation such as intrinsic motivation has a very narrow scope in cheating behavior which is a violation of academic integrity. This suggests there is a possibility that there are other factors that have a bigger role in influencing academic integrity. This can provide the possibility that there are other factors that have a bigger role in influencing academic integrity. Furthermore, researchers also argue that the absence of a relationship between learning motivation and academic integrity is probably due to the influence of other psychological perspectives which are components that can contribute to influencing behavior of academic integrity apart from a motivation perspective. One of them is the religiosity factor. This can be proven in the results, according Alia which states that the religiosity factor has an influence on academic integrity [24].

The possibility of the involvement of external factors which is a stronger factor in affecting academic integrity as evidenced in the research, according to Kabak that shows that there is a significant impact on external factors towards academic integrity. The external factors referred above can be in the form of competence in anxiety, academic policies, achieving good grades and also the environmental conditions of the classroom [25]. Contatry to Peled et al research, which states that there is a relationship between motivation and academic integrity. The difference in the results of this study is because in this study, it is argued that online learning can affect a person's motivation in the ability to learn independently which will substantially reduce the desire to cheat. Beside that, differences in the results of this study can be caused by the background of the research subjects such as the culture that they have [26].

\section{CONCLUSION}

Based on the results and discussion, the majority of students at the Faculty of Medicine - UPNVJ have good metacognitive ability (78.8\%), moderate learning motivation $(73.1 \%)$, and moderate academic integrity behavior $(75.6 \%)$. There is no significant relationship between metacognitive and learning motivation with academic integrity in students at the Faculty of Medicine , Universitas Pembangunan Nasional Veteran Jakarta in 2020 .

\section{AUTHORS' CONTRIBUTIONS}

All Authors contributed equally to this research. Destiana Putri conducted the experiments, analyzed the data also wrote the manuscript.

\section{ACKNOWLEDGMENTS}

This study was supported by Dean of Medical Faculty, Pembangunan Nasional Veteran Jakarta University. Biggest appreciation for the occasion in learning and collecting the data that provided by my committee especially dr. Hikmah Muktamiroh, M.Med. Ed and dr. Agneta Irmarahayu M.Pd.Ked.

\section{REFERENCES}

[1] Purnamasari, C.B., Claramita, M. and Prabandari, Y.S. (2015) Pembelajaran profesionalisme kedokteran dalam persepsi instruktur dan mahasiswa. Jurnal Pendidikan Kedokteran Indonesia: The Indonesian Journal of Medical Education, 4(1), pp.21-27. doi : 10.22146/jpki.25263

[2] Indonesia, K. K. (2006) Standar kompetensi dokter. Jakarta: Konsil Kedokteran Indonesia.

[3] Purnamasari, C.B., Claramita, M. and Prabandari, Y.S. (2015) Pembelajaran profesionalisme kedokteran dalam persepsi instruktur dan mahasiswa. Jurnal Pendidikan Kedokteran Indonesia: The Indonesian Journal of Medical Education, 4(1), pp.21-27. doi : 10.22146/jpki.25263

[4] Musharyanti, L., Rahayu, G.R. and Prabandari, Y.S. (2012) Persepsi dan perilaku mahasiswa keperawatan tentang integritas akademik. Jurnal Pendidikan Kedokteran Indonesia: The Indonesian Journal of Medical Education, 1(3), pp.200-211. doi : 10.22146/jpki.25106

[5] Ronokusumo (2012) “ Sekedar Kata atau Nyata?", Integritas Akademik sekedar kata atau nyata? Edited by S. Sungkar and A. Gabriella. Jakarta: Badan Penerbit Fakultas Kedokteran Universitas Indonesia.

[6] Nadeak, B. (2015) Etika Pendidikan Kedokteran. Jurnal Dinamika Pendidikan, 8(2), pp.123-129.

[7] Guraya, S.Y. (2018) Comparing recommended sanctions for lapses of academic integrity as measured by Dundee Polyprofessionalism Inventory I: Academic integrity from a Saudi and a UK medical school. Journal of the Chinese Medical Association, 81(9), pp.787-795. doi : 10.1016/j.jcma.2018.04.001

[8] Herqutanto. (2013) Plagiarisme, Runtuhnya Tembok Kejujuran Akademik. EJournal Kedokteran Indonesia, 1(1), pp.1-3. doi : 10.23886/ejki.1.1589.1-3

[9] Maharani, P. (2016) Hubungan Pola Asuh Orang Tua Terhadap Perilaku Integritas Akademik 
Mahasiswa Fakultas Kedokteran Upn Veteran Jakarta Periode Mei-Juli 2016. Skripsi, Universitas Pembangunan Nasional Veteran Jakarta.

[10] Muktamiroh, H., Prabandari, Y.S. and Sastrowijoto, S. (2015) Hubungan Antara Kepribadian Dasar dan Kapasitas Mental dengan Persepsi, Perilaku dan Intensi Integritas Akademik. Jurnal Pendidikan Kedokteran Indonesia: The Indonesian Journal of Medical Education, 4(3), pp.101-108. doi : 10.22146/jpki.25278

[11] Rinaldi. (2017). Kesadaran Metakognitif. Jurnal RAP UNP, 8(1), pp.79-87.

[12] Barida, M. (2017) Keterampilan Metakognisi Mahasiswa Program Studi Bimbingan Dan Konseling Terhadap Mata Kuliah Statistik. Jurnal Psikologi Pendidikan dan Konseling: Jurnal Kajian Psikologi Pendidikan dan Bimbingan Konseling, pp.46-54. doi : 10.26858/jpkk.v0i0.3461

[13] Lihawa, C. and Al Rasyid, H. (2016) Pengaruh Motivasi Kerja terhadap Kinerja Dokter dalam Kelengkapan Pengisian Rekam Medis dengan di Moderasi Karakteristik Individu (Studi di Rumah Sakit Islam Unisma Malang). Jurnal Aplikasi Manajemen, 14(2), pp.300-321. doi : 10.18202/jam23026332.14.2.12

[14] Natalya, L. and Purwanto, C.V. (2018) Exploratory and confirmatory factor analysis of the academic motivation scale (AMS)-Bahasa Indonesia. Makara Human Behavior Studies in Asia, 22(1), pp.29-42. doi : 10.7454/hubs.asia. 2130118

[15] Firmantyo, T. and Alsa, A. (2017) Integritas akademik dan kecemasan akademik dalam menghadapi ujian nasional pada siswa. Psikohumaniora: Jurnal Penelitian Psikologi, 1(1), pp.1-11. doi : 10.21580/pjpp.v1i1.959

[16] Önem, E. (2010) The relationship among statetrait anxiety, foreign language anxiety and test anxiety in an EFL setting. Dil Dergisi, (148), pp.17-36.

[17] Banga, C.L. (2014) Academic Anxiety Among High School Students in Relation to Different Social Categories. International Multidisciplinary $e$ Journal, 3(3), pp.73-87.

[18] Lisiswanti, R., Sanusi, R. and Prihatingsih, T.S. (2015) Hubungan motivasi dan hasil belajar Mahasiswa Kedokteran. Jurnal pendidikan kedokteran indonesia,4(1), pp.1-6. doi : 10.22146/jpki.25259

[19] Abdullah, R. and Soemantri, D. (2018) Validasi Metacognitive Awareness Inventory pada Pendidikan Dokter Tahap Akademik. Jurnal eJKI, 6(1), pp.15-23. doi: 10.23886/ejki.6.8621.Abstrak

[20] Natalya, L., 2018. Validation of academic motivation scale: short Indonesian language version. ANIMA Indonesian Psychological

Journal, 34(1).

[21] Wasityastuti, W., Susani, Y.P., Prabandari, Y.S. and Rahayu, G.R. (2018) Correlation between academic motivation and professional identity in medical students in the Faculty of Medicine of the Universitas Gadjah Mada Indonesia. Educación Médica, 19(1), pp.23-29. doi 10.1016/j.edumed.2016.12.010

[22] Andiwatir, A. and Khakim, A. (2019) Analisis Perilaku Menyontek dan Rancangan Perubahan Perilaku pada Siswa SMP. Intuisi: Jurnal Psikologi Ilmiah, 11(2), pp.88-97.

[23] Jiang, H., Emmerton, L. and McKauge, L. (2013) Academic integrity and plagiarism: a review of the influences and risk situations for health students. Higher Education Research \& Development, 32(3), pp.369-380. doi : 10.1080/07294360.2012.687362

[24] Alia, P. S. (2019) Faktor-faktor yang memengaruhi integritas akademik pada siswa SMAN Cahaya Madani Banten Boarding School (cmbbs). Bachelor's thesis, Fakultas Psikologi UIN Syarif Hidayatullah Jakarta.

[25] Kabak, E. (2020) Analisis Faktor-faktor yang Mempengaruhi Integritas Akademik Mahasiswa Keperawatan. JOEAI: Journal of Education and Instruction, 3(2), pp.110-122. doi : 10.31539/joeai.v3i2.1380

[26] Peled, Y., Barczyk, C., Eshet, Y. and Grinautski, K. (2012) March. Learning Motivation and Student Academic Dishonesty-A Comparison Between Face-To-Face And Online Courses. In Society for Information Technology \& Teacher Education International Conference (pp. 752759). Association for the Advancement of Computing in Education (AACE). doi : $10.23916 / 002017026010$ 